IJIET, e-ISSN 2548-8430, p-ISSN 2548-8422, Vol. 2, No. 1, January 2018

IJIET

International Journal of Indonesian Education and Teaching http://e-journal.usd.ac.id/index.php/IJIET

Sanata Dharma University, Yogyakarta, Indonesia

\title{
MORAL EDUCATION TO EMPOWER CONSCIENCE, MIND AND VOLITION TO IMPROVE THE QUALITY OF HUMAN BEINGS
}

\author{
Paulus Wahana \\ Elementary Education Study Program, Sanata Dharma University \\ paulus_wahana@yahoo.com \\ https://doi.org/10.24071/ijiet.v2i1.962 \\ received 8 September 2017; revised 30 November 2017; accepted 28 December \\ 2017
}

\begin{abstract}
Human beings are the highest form of God's creation among other creatures. Moral education is carried out to enable human beings to live up to their noble purpose of life as destined by God. In order to strive for their noble destiny, human beings have three spiritual powers that must be empowered and utilized in their lives, namely conscience, mind, and volition. In order for those powers to be useful optimally, they must be empowered. In order to empower conscience, it is necessary to cultivate silence in life so that we are able to listen to the gentle whisper of conscience which leads to a good life as the purpose in the journey of life. To prevent the conscience from straying, it needs to have a moral compass which would be the basis to determine the next steps. Furthermore, one should have clear mind to determine the ways, steps, means, and directions to arrive atthe expected goal. Finally, in order to realize the qualified life, which has been determined to be done, human beings have willpower to follow up. To determine and decide something, human beings must be courageous to take action. In order to be courageous to take action, we need to have a strong consideration that what we are doing is good and right. Thus, we will dare to be held accountable for any outcomes of the actions we have taken as right and just. That is, essentially, the true human destiny, namely to strive for goodness and truth.
\end{abstract}

Keywords: moral education, conscience, mind, willpower, quality life

\section{Introduction}

Human beings are the highest form of God's creation among all other creatures. Based on their destiny, human beings are not merely physical beings, but also spiritual beings, who possess creativity (cognitive), sense (affective), and willpower (co native) (Sudiarja, Subanar, Sunardi, and Sarkim, 2006: 233-249). As with all other living beings in nature, human existence takes place and is influenced by the law of nature (such as law of gravity). Human beings can slip and fall, can drown in the water, and like other creatures, human beings breathe and digest food. These activities take place naturally and automatically without any human involvement. However, as the highest form of God's creation, human beings conduct activities which are different from those done by other creatures. 
The activities are typical human activities, which can only be done byhuman beings, based on their spiritual ability. The activities typically done by human beings take place based on their feeling, thoughts, judgments, decision- making, as well as willpower, which then are manifested in physical actions (Montemayor, 1994:18). And just as they have unique spiritual abilities, human beings have obligation to act morally, functioning their spiritual power to the best of their ability to sustain the noble destiny as human beings.

Equipped with these strengths, human beings are expected to be the subjects of the law of nature, who realize and desire to do what they are doing. What they do is expected to be more than emotional drive or desire from within, not merely an effect or spontaneous reaction to external stimuli. In dealing with the internal impulses and external stimuli, human beings (as subjects) are expected to overcome, make judgments based on the law of nature, and make decision based on their free will. In utilizing their spiritual powers, they are expected to be serious instead of frivolous because spiritual powers must be used rightly in order to yield positive outcomes. In addition to resulting in the right decisions according to the pre-conceived and pre-determined goals, we also need to determine the aim and purposes in accordance with the noble nature of human beings.

As human beings, we do not just live this life aimlessly. With the freedom in our hands, we are called to live our lives nobly, to embody the positive values of life, and to avoid actions that result in negative values. According to Covey, human beings are expected to develop the spiritual powers to avoid being victimized by life circumstances, not being reactive to circumstances. Instead, human beings are expected to be the subjects of their circumstances, pro-active, capable of feeling, thinking, considering, and eventually making decisions to overcome and to handle life difficulties to realize better and more noble life values and to avoid negative things (Covey, 1989:66-67).

Unfortunately, human beings often live their lives being subjected to their circumstances. In life, these people passively accept fate as something they deserve, merely jumping into bandwagon, being enslaved by authoritarian rulers, being swayed by impulses from within themselves. Some even allow themselves to be enslaved by rules without even considering the relevance and benefits of those rules for their lives. Behaving in such a way, people stop from beingsubjects and start being objectified by the authority, the existing regulations, allowing themselves to be enslaved by passion, addiction, drug abuse, nicotine, sex, enjoyable worldly possessions (smart phones, television), which areconsidered as suitable to human instincts. People are no longer the subjects who have freedom, autonomy, ability to discern, decide, and make decision to act. Instead, they are bound by the enslavement.

To live our lives as subjects, instead of objects, it would be great if we realize who we are as noble creatures, which have freedom, autonomy, selfdetermination, and ability to make judgments, choose, make decision, and act in accordance to our life's goals and orientations. Despite being influenced by our inner drives and external stimuli, we are expected to have the ability to distance ourselves, overcome, and take a stand and take action. Human beings need to exercise their autonomy in relation to other people. People's autonomy is 
interpersonal as they are increasingly autonomous in relation to others. A higher degree of autonomy will improve the quality of interpersonal relationship (Bakker, 2000: 38-50).

In addition to being aware as noble creation, we need to know our strengths as spiritual beings, which have conscience, mind, and free will. In this paper, conscience, mind, and free will will be explained. After understanding the description of the three inner powers and how they function, we need to conduct moral education to empower them so they have an increasingly optimal role for the development of our life to become whole human persons who have integrity, are more autonomous interpersonally and interpersonally, are more valuable, have a positive attitude and ability in developing oneself interpersonally.

\section{Theory}

\section{The Role of Conscience}

According to Covey, people must begin with the end in mind. It means to start with a clear understanding of one's destination. It means to know where one is going so that one better understands where he is now and so that the steps taken are always in the right direction (1989:97-99). The fundamental problem of human life lies precisely in the awareness of goals to be reached based on the current state, namely the values and qualities deemed necessary to be realized.

Humans have freedom and autonomy in determining the direction and destination of their lives, but this freedom requires human beings to be responsible as noble creatures, morally obliged to realize positive values and avoid negative values. The mind clearly has a role to gain clarity of the roads to take, the guiding signs that need to be addressed, the various obstacles that need tobe dealt with, the means used, and the ways and actions taken to realize the intended purpose. But the direction to be cultivated must be determined by the conscience that is called on to the good value / quality to be realized. Therefore, the activities of the human mind must originate from what the conscience deems good for the purpose.

Although human beings have free will to choose and act, in fact they cannot choose arbitrarily; and due to the fact that it is a conscious act that human beings need to be held accountable for their actions (Makmurtomo: 23-24). In order to hold accountable for the actions, human beings are endowed with sensibility in their hearts, which always accompany them and raise human beings' awareness toalways do good and avoid evil. When humans face the circumstances and problems in their lives, they have moral consciousness to feel, make judgments in making decisions based on their conscience that human beings are obliged to do good and avoid evil (Bertens, 2013: 41-42).

Awareness to do good and avoid evil always assists human (conscience) in making decision to take action. The conscience is a moral consciousness that is naturally formed inside human beings. Human beings have inherent potential to choose to do good and avoid evil since they were born. However, the picture of good (which needs to be chosen), and evil (to be avoided) are formed and awakened in the course of human life. In order to consider and make decisions to 
do good, and avoid evil, conscience needs to have reasons as the basis for its consideration.

Conscience is the appreciation of good or evil in terms of our concrete behavior. Conscience commanded to do good or forbid us to do evil now and here; in more concrete terms: we should do good things and avoid doing evil things. Before an ethical / moral action will take place, the conscience will tell whether it is good or bad. If the action is deemed good, the conscience arises as a commanding voice. However, if the action is deemed evil, the conscience will serve as a restrictive voice. When an action is executed, the conscience still works, by commanding or forbidding. After an action or deed is completed, the conscience arises as a "judge" who gives a verdict. For good deeds, conscience will gratify, thus making people feel proud and happy. However, if the act is bad or evil, then the conscience will denounce / blame, so that people feel anxious, embarrassed, sorry, or desperate.

Conscience is personal, ultra personal, and rational. Being personal means being always closely related to the person concerned. It deals with him and the actions he concretely does, and not giving judgments to the deeds of others. The conscience is also ultra personal, beyond personal, transcendental, as if it were the institution above us; in which we submit to be only listeners, open ourselves up to something coming from the outside / up, and which overcomes as the conscience, the inner voice, the voice that comes from within us. The conscience is rational, because the conscience rationally assesses. But the decision given by conscience is usually direct, intuitive, as though not through argumentation or rational reasoning measures.

\section{The Role of Mind}

In addition to the conscience, we will discuss the power of another spiritual ability, namely the power of the human mind. We have discussed that conscience is the power that provides the basis, direction, and purpose for action so as not to get lost, but can capture and realize a good life, a quality life, in harmony with the nobility of our human nature. Next, we need to discuss the power of human mind that is expected to be able to think, consider, and decide properly the appropriate direction-goals, paths, means, and ways to be used to realize a good life, a life of value and quality.

Thinking Activity starts when it is triggered by the question or problem, either from others or from within. The question arises in order to obtain information or clarity regarding the question. So the main question is none other than a petition; while the answer is a statement that provides information on the question asked. The thought of making / generating a statement is the thought of searching for and finding information that is appropriate and relevant to what the information is asking for. The requested and thoughtful description of the question relates to the question word being used.

What is done in the thinking activity of answering and giving explanation is: searching for an appropriate explanation in accordance with what is described. Furthermore, the things described and explained are arranged or linked in an explanatory statement. In addition to choosing to seek and find information or explanations, what needs to be thought of is that the information (predicate) needs 
to have conformity and the relationship with the described (subject), so that the resulting statement is the correct statement. A statement is said to be true if the relationship in the statement is indeed in conformity with reality (correspondence truth); if it is in accordance with other statements which are the basis of thought (coherence truth); and if the cause-effect relationship is indeed in accordance with its implementation (pragmatic truth).

The statement explains whether there is a relationship between understanding one with another; a positive statement indicates a relationship, whereas a negative statement indicates there is no relation between the meanings in the statement. Each statement provides explanation. Each statement contains at least two things, namely about the explained and the explanation. The statement directly or indirectly provides answers, in the form of explanation or information we ask based on what we need to get an explanation. Based on the question wordswe usually use, there is an explanation we expect, for example: <who> needs information about the person involved (as subject, object, complement), <what> requires information about the related item, <where> requires information about a place, <when> requires information about time, <why> requires information about the reason or cause of a circumstance, and $\langle$ how $\rangle$ requires information about the occurrence of an event or circumstance.

In addition to being triggered by questions or issues that require answers containing correct information, the thinking activities are also triggered by a problem that needs to be resolved. The problem in the first sense is the existence of gaps faced and felt by the person concerned that need to be overcome, namely the gap between the experienced reality and the hopes or ideals to be realized. While in the next sense, the problem is all the obstacles, difficulties, predicaments faced by human beings (both in themselves and outside themselves) that need tobe faced and resolved in order to achieve the desired or expected goals.

The thought that one can solve a problem refers to the ability to think about how to reach the desired goal. This needs clarity and truth of the goal to be achieved. After obtaining the necessary relevant and correct information on the goal, it is necessary to think about the paths to be taken, the means used, and the ways to do it. All of these must be thought about to gain the clear and correct interconnectedness among the components, in terms of goal, ways, means and paths to realize the goal, namely better, valuable and qualified life.

\section{The Role of Free Will/Willpower}

In addition to having a conscience to guide them to good life goals, which are worth striving for, and creativity to help them understand everything better in order to face challenges to achieve more valuable life, human beings also havefree will to choose their actions to realize the kind of life they are dreaming of. In addition to conscience and mind, human beings also have willpower to perform the actions they have chosen.

Volition is one of the human's spiritual powers meant to achieve a goal; the goal is the final destination of a goal-oriented movement. Willpower is human's spiritual power to achieve a goal. Volition is the man's inner strength, which arises and intertwines with man's feelings and thought. Volition does not arise 
spontaneously, but it arises as a result of consideration based on the feelings and thoughts to realize decision making process (Ahmadi, 2003:113-116).

Volition is the inward impulse of the human being higher than instinct, reflex, automatism, habit, lust, desire, inclination, and lust. Volition or willpower belongs only to human beings, as beings with conscience and thought. Volition is the conscious inner impulse, based on the consideration of the feelings of conscience, mind power, and the whole person of man which leads to activities directed towards the achievement of a particular purpose related to his personal needs.

Based on the above explanation, the characteristics of volition and willpower can be described. Volition is human's inward impulses, because volition is a conscious impulse to be considered. Volition is interrelated with one purpose, driving human activities to attain a certain predetermined goal. Volition as a driving force of human action is based on several considerations, such as conscience which determines whether an action is good or bad, and the personal consideration and influence which can give nuances to the so-called action (Ahmadi, 2003: 125-126).

Some aspects affecting volition: a) influence related to physical conditions, namely the willingness, ability, and capability to act upon the volition; b) instruments, requirements, and tools used to carry out the volition; c) whether the milieu or environmental circumstance is conducive or otherwise; and d) conscience (consciensia) plays a significant role in carrying out the decision of the will (Ahmadi, 2003:138).

\section{Theory Application}

\section{Moral Education to Build a Qualified Life}

As the highest form of God's creation, human beings can perform activities that are more than other beings, which are not only driven by physical, biological, or psychic impulses. But human activity can take place based on the spiritual ability of man. Typical human activity takes place on the basis of feelings, thoughts, considerations, decision-making, and then there is the will to do it.

With these advantages, man is expected not only to function as an object, but also as a subject, who realizes and wants what he does. So, the activities undertaken by humans are not merely the effect of instinctive drives from within, or just a reaction to stimuli directed at him. In the face of internal instinctive drives and the external stimulus, it is expected that humans (as subjects) take into account some considerations, thoughts, and then make the decision of the will to act upon it. And in exercising the spiritual powers, of course, human beings should not be inconsequential, as these powers must be used properly so as to make the best and righteous decision to realize a good life.

This level of ability is not necessarily possessed by humans, but human beings need to learn and seek for its development. According to Covey (1989: 66- 77), human beings are expected, through education, to develop their spiritual power so that people do not fall victim to the situation; so they are not reactive to the situation but are capable of being the subject in dealing with the situation; and are pro-active and capable of feeling, thinking, considering, and ultimately 
making a decision to handle and deal with the situation which will bring about a better and more dignified life.

Although in terms of position and composition, the nature of human is the highest form of creature among other beings, man is not by himself capable of placing himself and functioning the power in him to manifest his life as a noble being. Being noble implies being a subject, an autonomous subject, who is capable of considering, making decisions, having the freedom, and being responsible for directing and realizing a life of value. Moral education is human effort to direct his typical actions as human beings, to do it autonomously, consciously, freely, and to be directed to a good and valuable life. Therefore, moral education raises our awareness that humans have a noble position as autonomous beings, which have spiritual resources to organize and direct this life in accordance with his will, i.e. to realize a noble life. In this paper, as humans have positions as autonomous beings and possess the nobility of spiritual powers, presumably through moral education, we need to empower the spiritual powerswe possess in order to bring about a better and upgraded life, as our destined vocation.

Conscience serves as a guide, a compass, or a norm to judge an action, whether it is good or evil. Conscience serves as standards or concrete rules in everyday life. Conscience serves to alert people of their value and self-esteem. Recognizing the image and the significant role of the conscience to direct human life, we need to respect the voice of our conscience, listen to every whisper carefully, consider it and then do what the conscience actually says.

Bearing in mind that conscience is personal, we need to have a basic moral principle that we believe and can be used as a reference, the basis on which we base our action. Conscience directs people to do good and avoid evil. In order to avoid evil, we are expected not to commit a crime, neither to harm ourselves nor others. We are at least required not to make other people miserable. And in order to work for good, we need to take account of the benefits of all parties involved, and choose actions that will bring good results outweighing the consequences. In addition to manifesting good and avoiding evil, we also need to pay attention to justice. It means to treat everyone fairly and to give them their rights equally. And the last principle is that we need to treat ourselves and other human beings as autonomous beings, so that every human being as subject is expected to be accountable for the actions taken on his own choice. (Sudarminta, 2013: 170-176). Without basic moral principle to serve as a basis for judgment, there will be no reference to direct people to a good life. People may get lost in finding their life goal, for example: doing an act that gives pleasure to him but harming his fellow human beings; taking actions that provide the greatest advantage for himself without regard to justice for others. Even people can get lost in doing good in the name of religion or God, for example on the pretext of religion / God, people seek for personal or group gain (e.g. in economic or political) by harming, treating unjustly, even causing others to be miserable.

In addition to a universal basic moral principle, we need to remain open to enlightenment, so that we are increasingly having a wider moral insight. We need 
to have an honest and non-hypocritical attitude, so that we can easily identify things that would obscure and even mislead the direction of our destiny. Then, to achieve a quality of life; we also need to be silent to hear our conscience speakand to have clarity in thinking, to hear the gentle whisper of conscience in the hustle bustle of life to be able to see the direction of life clearly and to see the direction that misleads us.

In order to develop a conscience (as conscientia $=$ real and personal knowledge), we need to place our conscience in the context of real / concrete life. Either directly or through media, we need to be constantly faced with the problems of life that need a wise moral judgment, involving conscience, mind, and the decision of the will to be followed up. In the context of life bearing the moral problem, through understanding and reflection, we are able to position ourselves and feel with conscience whether the action is good or bad. Through value clarification and analysis, it is hoped that we will be able to choose positive things and avoid negative things. In contrast to the thinking process (subjects who think against the object being thought), reflection is the activity of understanding how a subject experiences, understands, and experiences itself in relation to others. In addition to understanding, we can also feel, and even evoke emotions in relation to what we reflect and ponder. So we need to create an atmosphere that is expected to touch our hearts, to be able to feel the moral issues of the things we face, and to find an attractive positive value to be realized, or the negative value toavoid.

In addition to conscience, human thought or creativity needs to be developed in order to be intelligent: able to analyze (elaborate) issues, to understand the parts, to understand the interconnectedness of each part, to understand the causal relationships between things; and to be able to synthesize (assemble) the existing parts, to realize a systematic unity of thought from the information or knowledge it possesses. Thinking leads to enlightenment / explanation / description, thus gaining a clear or correct understanding or description of the interrelationship of what is being thought about. This clear and correct understanding develops further, broader, deeper, more detailed knowledge, serving as the means to make decisions to solve real problems in life, and torealize the values of their lives. For example, people who are lost in their journey will find help from a map that provides clear and correct information / images of roads to get to the destination. Similarly, understanding of the engine gear system and all its parts will help a motorcycle mechanic to find and fix mechanical problems.

To judge and manifest a good life of value, it would be necessary to relate between the actions having been done and the actions believed to be good / valuable, according to moral principles. A good life is shaped through human's actions on a day-to-day basis. Good actions are relevant actions, which are expected to support the formation of a good life. The good life, the life of value, isa quality life in harmony with our natural human tendencies as noble creatures. The good and valuable quality life orients human beings to realize it. For example: as physical creatures (physical, biological), human beings hope to be healthy, empowered, and skilled. As spiritual beings, human beings hope to 
develop and function optimally, overcome life problems, have sensitivity of conscience in relationship with themselves, others, and God, and have a strong will to realize good things. As social beings, they hope to live harmoniously, cooperatively, and graciously with the social and natural environments where they belong.

Conscience leads to a valuable life, and creativity provides a clear and correct understanding of various issues and problems faced on the way to achieve the purpose of life. Volition and willingness to be free to choose the actions are necessary. Thus, in addition to awareness of conscience and thought, humans also have volition to perform actions. However, even though human beings have made decision and have a free will to choose an action, humans do not just choose arbitrarily. Since action is conscious, man needs to account for his actions as a good or valuable action (Makmurtono, 1989: pp. 23-24). In order to account for their actions, humans must desire and do the best and avoid evil; as much as possible striving for the positive and noble values and avoid negative and trivial values (Wahana, 2004: 55-57).

Everything we do must be weighed by conscience in search of a quality of life through ways and means which support the realization of the goals. Therefore, we must be full of courage to desire and do it because we have faith in the goals which direct our life. In addition to having the courage to do, we also need to have courage to account for what we do, both with regard to process and outcome as a result of our actions. Although we have a solid consideration to do and account for it, we must implement it carefully so as to realize the goals of a more valuable life.

\section{Conclusions}

Humans are the highest form of God's creation. As the noblest creation, human beings have freedom to act according to their choice and will. In order to realize its nobleness, humans have various means to realize their life of value.

Unlike other God's creations, human beings are privileged to have conscience, mind, and free will. To function properly, these devices must be empowered to improve the quality of life as we are morally called for.

Moral education as the education of values is expected to improve theability of the mind to understand the value (value knowing), of the conscience feeland live value (value feeling), and of the will to realize the value (value doing). Moral education empowers three special tools in the following ways:

1. Conscience needs to seek a silence, so that the gentle voice of the conscience can be heard in the hustle bustle of human activities. Although our conscience is subjective and personal, we may need to have a general moral principle to base our judgment to take a decision of action.

2. The power of human mind can help human beings to gain a clear and correct understanding, which serves as the way, means, and methods to solve problems, to achieve the highest quality of life.

3. Willpower or volition contains power that can encourage people to act in accordance with the conscience and mind. Willpower will work if we have 
a strong conscience and mind. So we need to take action with courage, and account for the consequences of our actions.

In this way, human beings are expected to become more conscientious and sensitive to do good and avoid evil, and to solve various problems intelligently, and have a strong will and concern to realize a life of value.

\section{References:}

Anonymous. (2010). Filsafat ilmu pengetauan. Yogyakarta: Pustaka Diamond.

Ahmadi, A. (2003). Psikologi umum. Jakarta : Rineka Cipta.

Covey, S.R. (1989). The seven habits of highly effective people. New York: Fireside Simon \& Schuster Building Rockefeller Center.

Elmubarok, Z. (2009). Membumikan pendidikan nilai. Bandung: Penerbit Alfabeta.

Frondizi, R. (1971). What is value?: An introduction to axiology. La Salle: Opencourt Publishing Co.

Magnis, S.F. (1987). Etika dasar. Yogyakarta: Kanisius.

Makmurtomo, A., \& Soekarno, B. (1989). Etika: Filsafat moral. Jakarta: Wira Sari.

Montemayor, F.M. (1994). Ethics: The philosophy of life. Metro Manila: National Book Store, Inc.

Mulyana, R. (2011). Mengartikulasikan pendidikan nilai. Bandung: Alfabeta.

Poespoprodjo, W. (1986). Filsafat moral. Bandung: CV Remadja Karya.

Scheler, M. (1973). Formalism in ethics and non-formal ethics of values. Evanston: Northwestern University Press.

Sudarminta, J. (2013). Etika umum: Kajian tentang beberapa masalah pokok dan teori etika normatif. Yogyakarta: Kanisius.

Sudiarja, A., Budi S.G., Sunardi, S.T., \& Sarkim, T. (2006). Karya lengkap driyarkara: Esai-esai pemikir yang terlibat penuh dalam perjuangan bangsanya. Jakarta: PT Gramedia Pustaka Utama.

Suparlan. (2004). Mencerdaskan kehidupan bangsa: Dari konsepsi sampai dengan implementasi. Yogyakarta: Hikayat.

Tauchid. (2013). Ki Hadjar Dewantara I tentang pendidikan. Yogyakarta: Penerbit Universitgas Tamansiswa bekerjasama dengan Majelis Luhur Persatuan Tamansiswa.

Wahana, P. (2004). Nilai etika aksiologis max scheler. Yogyakarta: Penerbit Kanisius. 